\title{
ArcheoSciences
}

Revue d'archéométrie

\section{Treasures of Portuguese archaeology Notes towards a preventive conservation project}

Trésors de l'Archéologie portugaise - notes pour un projet de conservation préventive

Isabel Tissot, Matthias Tissot, Pedro Pedroso and Luís Raposo

\section{CpenEdition}

\section{Journals}

Electronic version

URL: http://journals.openedition.org/archeosciences/2504

DOI: $10.4000 /$ archeosciences.2504

ISBN: 978-2-7535-1598-7

ISSN: $2104-3728$

\section{Publisher}

Presses universitaires de Rennes

\section{Printed version}

Date of publication: 31 December 2009

Number of pages: 389-392

ISBN: 978-2-7535-1181-1

ISSN: $1960-1360$

\section{Electronic reference}

Isabel Tissot, Matthias Tissot, Pedro Pedroso and Luís Raposo, «Treasures of Portuguese archaeology Notes towards a preventive conservation project», ArcheoSciences [Online], 33 | 2009, Online since 10 December 2012, connection on 05 May 2019. URL : http://journals.openedition.org/ archeosciences/2504; DOI : 10.4000/archeosciences.2504 


\title{
Treasures of Portuguese archaeology Notes towards a preventive conservation project
}

\section{Trésors de l'Archéologie portugaise - notes pour un projet de conservation préventive}

\author{
Isabel Tissot*, Matthias Tissot*, Pedro Pedroso* and Luís Raposo**
}

\begin{abstract}
The permanent exhibition "Treasures of Portuguese Archaeology" of the Portuguese National Archaeological Museum is composed mainly of gold and silver artefacts which present extensive surface corrosion. The construction of the exhibition room dates from the late 1980s, and it was conceived with the highest security standards in mind. However, at that time, the importance of the choice of compatible materials and equipments for the exhibition of metal artefacts was still unknown, and the same was true for the influence in terms of corrosion development, even for gold objects, if an inappropriate material was selected. Preventive conservation directives and actions have been developed since then, and presently one is confronted with new paradigms for the exhibition and preservation of artefacts, and, moreover, of cultural heritage. A preventive conservation project, which is currently in its initial stages, was set up with the objective of identifying and understanding the pathologies observed, in order to correct the problems presented by the exhibition room. This article presents an overall view of the project, a description of the alterations observed, and a summary of the methods proposed for obtaining responses to the respective problems, with the purpose of correcting the room's fragilities.
\end{abstract}

Resumé : L'exposition permanente "Les trésors de l'archéologie portugaise» du Musée National d'Archéologie est essentiellement composée de pièces en or et en argent qui présentent une surface de corrosion étendue. La salle d'exposition date de la fin des années 80 et a été conçue en respectant les normes restreintes de sécurité. Néanmoins, à cette époque, l'importance du choix de matériaux de construction et d'exposition des objets en métal était encore inconnue ainsi que l'influence, si le choix est incorrect, que ces matériaux exercent sur le développement de mécanismes de corrosion, même dans le cas d'objets en or. Nous avons assisté depuis à de nouveaux développements et directives concernant la conservation préventive et aujourd'hui nous sommes confrontés aux nouveaux paradigmes concernant l'exposition et la préservation des objets de notre patrimoine culturel. Il a été mis en place un projet de conservation préventive pour identifier et comprendre les pathologies observées, afin de corriger les problèmes de la salle d'exposition. L'article présente un aperçu de l'ensemble du projet, la description des altérations observées et les méthodes proposées pour obtenir les réponses aux problèmes observés afin de corriger ces erreurs.

Keywords: Ancient jewellery, gold and silver alloys alteration, preventive conservation, exhibition materials.

Mots-clés : orfevrerie archaïque, alliages en or et en argent, conservation préventive, matériaux d'exposition.

\section{INTRODUCTION}

The Portuguese National Archaeological Museum (MNA) possesses in its collections a remarkable number of ancient jewellery objects, either originating from excavations, or, more frequently, bought either from goldsmiths or the people who found them. This collection, due to its representative quality, allows a general overview of the evolution of this art in the present Portuguese territory, from the begin-

*Archeofactu - Rua do Cerrado das Oliveiras, no14 2Dto. 2610-035 Amadora, Portugal. (isabel.tissot@archeofactu.pt)

** Museu Nacional de Arqueologia - Praça do Império, 1400-206 Lisboa, Portugal. (mnarq.info@imc-ip.pt) 
nings of metallurgy until the Early Middle Ages (Parreira and Vaz Pinto, 1980).

The collection is on display in the "Treasures of Portuguese Archaeology" permanent exhibition, inaugurated in 1980. The exhibition room was conceived and built according to the highest security standards, reflecting the value of the collection, consisting mainly of gold artefacts (circa 700). Even today, the concept of value is deeply associated with the erroneous idea of the inalterability of gold artefacts; however, most of them are composed of gold alloys, in which the minor elements can corrode. Also, 20 years ago, preventive conservation was still in its early development stage; concerns related to the exhibition of objects and collections were focused on different issues, like security. The choice of stable and compatible materials for showcases was not a first priority, because it was still largely unknown. In contrast, today, museum professionals possess at least a basic understanding of preventive conservation, even if, as a new conservation field, it is still evolving and searching for models (Cassar, 2000). This evolution reflects the interesting paradigm pertaining to preventive conservation parameters related to the exhibition of objects, and, in this particular case, of gold objects.

\section{The Treasury Room - a secure room TO PROTECT A PRECIOUS COLLECTION}

The National Archaeological Museum is situated at the Virgin of Belém Monastery, generally known as Jerónimos Monastery, in Lisbon, occupying an area of almost $200 \mathrm{~m}$, corresponding to the original dormitory of the monastery (Fig. 1). The stone foundation of the monastery dates from

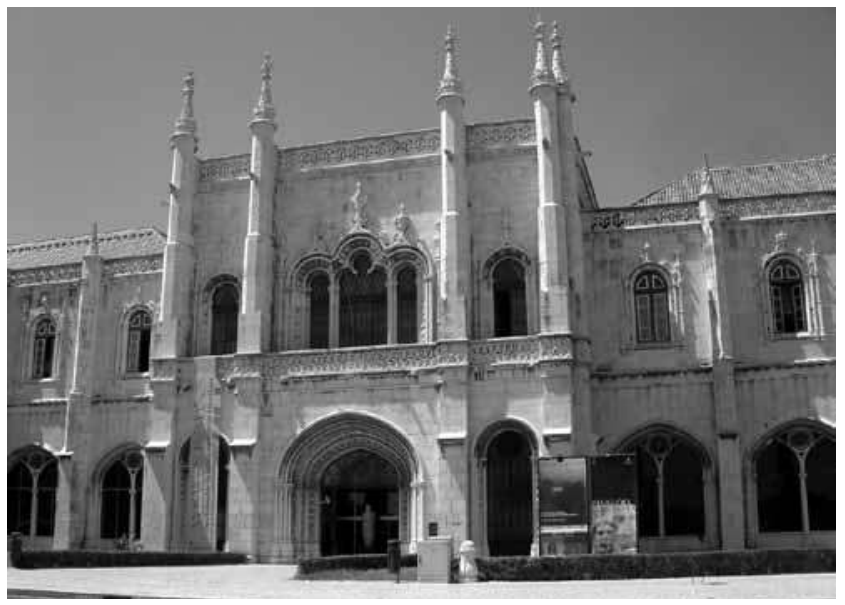

Figure 1: The Portuguese National Archaeological Museum. Figure 1: Le musée ational d'Archéologie du Portugal. the $15^{\text {th }}$ century and is located $250 \mathrm{~m}$ north of the Tagus river and $8 \mathrm{~km}$ away from the river mouth.

In 1980, in the east gallery, the Treasury Room was built, as a structure of aluminium, glass, wood, and wooden shavings. The walls and the showcases were covered by tissues and carpeting on the floor. The room has air conditioning equipment that regulates only the temperature at $20^{\circ} \mathrm{C}$, and the relative humidity $(\mathrm{RH})$, varies during the year between 40 and $80 \%$, with an average value of $65 \%$.

The exhibition still has a current context, notwithstanding the fact that it presents a maladjusted and outdated aesthetic (Fig. 2). In 2000, a small room renewal was performed, consisting of the replacement of the showcase fabrics and of the room carpet, as they displayed colour alterations and deterioration. At that time, no structural changes were considered, and no adequate material analytical study was carried out. Nevertheless, some attention was given to the selection of materials, in an attempt to make them compatible with the ones from the objects themselves; more specifically, the application of fabric composed of pure cotton was planned. During this change, a conservation treatment of the artefacts was performed.

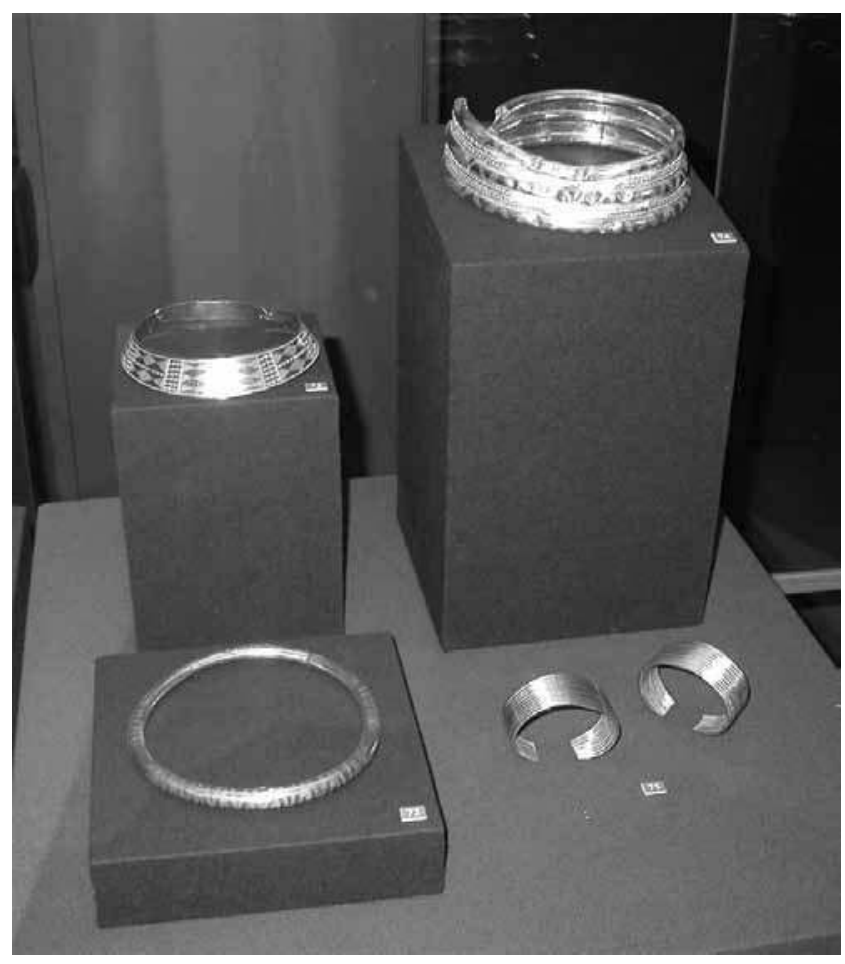

Figure 2: (See colour plate) Showcase from the exhibition "Treasures of Portuguese Archaeology" of the Portuguese National Archaeological Museum.

Figure 2: (Voir planche couleur) Les vitrines de l'exposition "Trésors de l'archéologie Portugaise " du musée National d'Archéologie. 
Only a few years later, a significant alteration of the surface of the metal objects could be seen (Fig. 3). The silver alloy artefacts presented a tarnished surface with a variation between yellow, brown, violet, blue and black blue, characteristic of silver sulphide, the main component of silver atmospheric corrosion (Selwyn, 1990). The surface of some of the gold alloy objects presented a rose coloration in some areas, also with a multihued iridescent effect. Although representing, apparently, a random effect, the alteration tended to appear to a more significant extent in areas of fissures, in surfaces that were in contact with the showcase fabrics, and in the objects with a silver content in the range of $20 \%$, based on the spectrographic analyses presented in the studies carried out by Hartmann (1970; 1982), the only analytic studies performed until today on the objects from the collection. The alteration that was observed could be a result of the formation of silver sulphide from the silver component in the alloys (Járó and Tóth, 1997) and the sulphide source originating from the materials of the showcases.

In order to understand the causes of this deterioration, a simple corrosiveness test, an accelerated corrosion test, based on the Oddy Tests (Hatchfield, 2002; Tétreault, 1999) was carried out in order to assess the effects of the materials from the exhibition room on the artefacts. These tests are merely indicative of whether the materials can be deleterious to the metals exposed.

The test consisted in placing the materials - tissue, wood, wood shavings and carpet - in separate reaction vessels, some containing pure silver, and others pure copper test coupons $(20 \times 10 \times 0.05 \mathrm{~mm})$, maintained at $60^{\circ} \mathrm{C}$ with $100 \% \mathrm{RH}$ over a 30 days period. At the end of this period, the metal coupons were assessed for visual alterations; the possible hazards are indicated by the severity of corrosion on the test coupons.

From the results obtained, it is practically impossible to distinguish the slight alterations in the copper test coupons, indicating there was no severe corrosion. The silver coupons showed no alteration when placed together with the carpet, wood and wood shaving materials, but presented a severe tarnishing in the coupon tested with the tissue. These results suggest that, although pure cotton tissue was considered an acceptable material for the exhibition, there is a problem with this material, which can be related to a dye or a fabric surface treatment, further testing being necessary to clarify this.

Notwithstanding the fact that the tissue was identified as one of the causes for the accelerated development of the corrosion processes registered on the artefacts, the deficient showcase system, which allows particle entrance and accumulation, should also be taken into consideration.

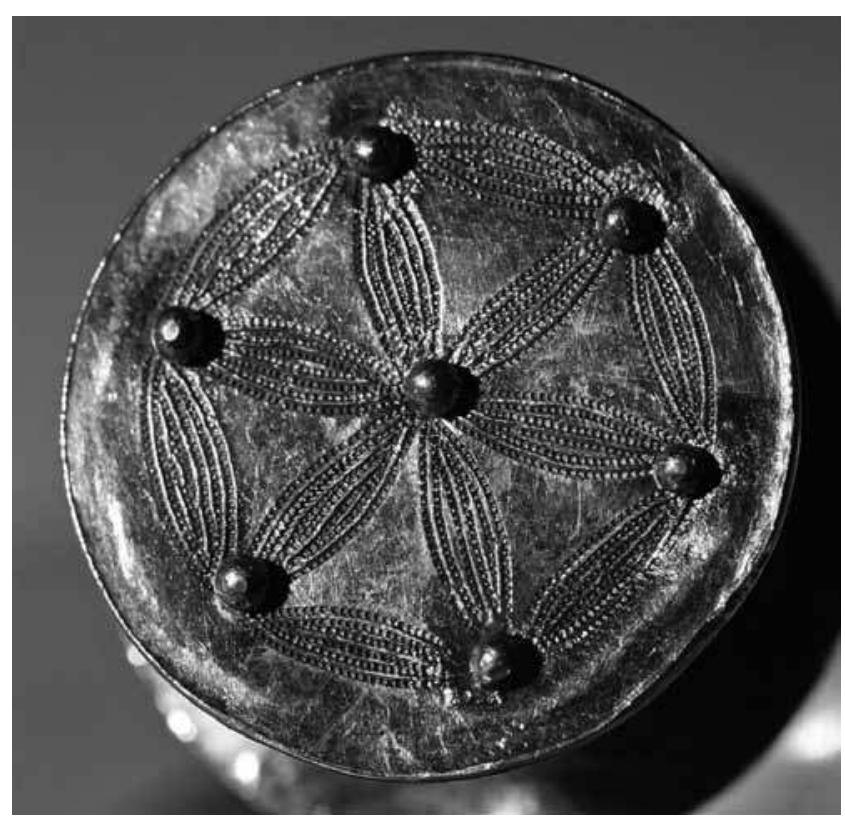

Figure 3: (See colour plate) Detail from a torc illustrating the corrosion of the surface.

Figure 3 : (Voir planche couleur) Détail d'un torque illustrant la corrosion sur la surface.

In light of these first tests, and with the aim of extending further the study of the Treasury Room, the MNA decided to put together a project involving the study of the material, not only in view of the conservation issues concerned, but also of the collection as an assemble. This includes a detailed study of the materials and equipment from the current exhibition room, and air quality analyses, allowing an assessment of the characteristics of the materials as potential deterioration sources, through their correlation with the pathologies observed. The aim is to apply the preventive conservation guidelines for an exhibition site in order to guarantee the conservation and appraisal of the collection. This project will also consider the diagnosis of conservation conditions and the treatment of the objects on display, c. 700, as well as a further remodelling of the room, accompanied by the development of a preventive conservation programme that will follow the evolution of the objects in the remodelled room in the future.

To this purpose, a team of specialists was assembled, where the synergies of various disciplines, including archaeology, preventive conservation, restoration and conservation, chemistry and physics, can be effectively targeted in an interdisciplinary endeavour to achieve the goals of such a project of preventive conservation. 


\section{Conclusion}

Today, the conception, organization, selection of materials and showcases for cultural heritage exhibitions is a major and complex issue which requires detailed study, although some research guidelines already exist (Tétreault, 1994; Hatchfield, 2000), and experimental rules for standardizing procedures in collections conservation have started to emerge (Borges de Sousa et al., 2007; Afnor, 2007).

These new trends in conservation can be associated with the most recent paradigms regarding preventive conservation parameters (Pereira, 2007), valuing the collection beyond its material value, as a cultural identity. This is an aspect which undoubtedly represents an inflection of the concept of heritage, which establishes cultural heritage and the assumption of preventive conservation as parts of the concept of the sustainability of objects and collections.

The principal aim of sustainability is to achieve an acceptable quality of life for the population of the world, combined with the economic growth of communities, without depleting or damaging the natural resources needed to sustain future generations. This concept can be applied to the present global sense of preventive conservation and its relationship with cultural heritage (Cassar, 2000).

Presently, in order to enhance the value of the collection, the MNA is planning a study aiming to identify, understand and correct the fragilities of the Treasury Room, ensuring the conservation of objects in the long term, and involving the new paradigms of conservation following the statement: 'Cultural heritage as a contributing factor to human development'.

\section{References}

Association Française de Normalisation, 2007. Normes expérimentale AFNOR XP X80-002 décembre 2007: Conservation de biens culturels - Recommandations pour concevoir, aménager, choisir et utilise rune vitrine d'exposition des biens culturels. Saint-Denis-la-Plaine, AFNOR.

Borges de Sousa, C., Amaral, J. and Tissot, M., 2007. Plano de Conservaçẫo Preventiva Bases orientadoras, normas e procedimentos. Lisboa, Instituto dos Museus e da Conservação.

Cassar, M., 2000. Value of Preventive Conservation. European Preventive Conservation Meeting. Vantaa, Institute of Art and Design.

Jaró, M. and Tóth, A., 1997. Deterioration of metal threads and other metallic decorations made of gold, silver, or gilt silver on Museum textiles - problems of their conservation, in Metal '95: Proceedings of the International Conference on Metals Conservation. London, James \& James, 201-208.

Hartmann, A., 1970. Prähistorische Goldfunde aus Europa. Studien zu den A,fängen der Metallurgie 3:1. Berlin, Mann.

Hartmann, A., 1982. Prähistorische Goldfunde aus Europa. Studien zu den Anfängen der Metallurgie 3:2. Berlin, Mann.

Hatchfield, P., 2002. Pollutants in the Museum Environment: Practical Strategies for Problem Solving in Design, Exhibition and Storage. London, Archetype.

Parreira, R. and Vaz Pinto, C., 1980. Tesouro da Arqueologia Portuguesa no Museu Nacional de Arqueologia e Etnologia. Lisboa, Secretaria de Estado da Cultura, Instituto Português do Património Cultural.

Pereira, H., 2007. Contemporary trends in conservation: culturalization, significance and sustainability. City \& Time 3(2): 15-25.

SelwyN, L., 1990. Historical silver: storage, display and tarnish removal. Journal of the International Institute for Conservation - Canadian Group (IIC - GC) 15: 12-22.

TÉtreault, J., 1994. Display Materials: The Good, the Bad and the Ugly. Edinburgh, Scottish Society for Conservation and Restoration (SSCR) Exhibition and Conservation Preprint.

TÉtreault, J., 1999. Revêtements pour l'exposition et la mise en réserve dans les musées. Bulletin Technique $\mathrm{n}^{\circ}$ 21. Ottawa, Institut Canadien de Conservation. 